\title{
A multiplexed work-flow for absolute quantification of Klebsiella oxytoca Nif proteins
}

\author{
Christoph James Waite*1, Anya Lindstrom Battle*2, Mark Bennett ${ }^{1}$, Martin Buck ${ }^{1}$ and Jörg \\ Schumacher ${ }^{1+}$ \\ ${ }^{1}$ Imperial College London, Department of Life Sciences, London SW7 2AZ, UK \\ 2 University of Oxford, Department of Engineering, Oxford, OX2 OES, UK \\ * equal contributing authors \\ † corresponding author: j.schumacher@imperial.ac.uk
}

\begin{abstract}
Global imbalances of the nitrogen cycle are increasingly recognized as a major challenge to human development, and are exacerbated by the use of synthetic inorganic fertilizers. Biotechnology alternatives to inorganic fertilizers include biofertilisation from nitrogen fixing bacteria (diazotrophs), expressing nitrogenase and auxiliary genes (nif genes). In order to directly quantify all twenty Nif proteins through multiple reaction monitoring (MRM) MS, we established a high throughput pipeline to generate a set of Klebsiella oxytoca Nif protein QconCATs as quantotypic standards. A stringent validation of the pipeline and QconCATs application with regards to isotopic labelling efficiency $(100 \%)$, limits of detection and quantification, analyte to internal standard concentration boundaries was used for optimisation. Using three QconCATs for the measurement of 20 likely low, middle and high Nif protein abundances enabled detection of all Nif proteins, 19 of which could be accurately quantified and their variation over time monitored. Stoichiometries between Klebsiella oxytoca Nif proteins and changes between early and late transition into diazotrophy suggest i) a temporal regulation of $n$ if gene cluster expression that may be linked to nitrogenase expression and maturation; ii) vast disparities in Nif protein abundances and iii) high dependency on the nifLA master regulator pair for nif gene expression.
\end{abstract}




\section{Introduction}

Global imbalances of the $\mathrm{N}$ cycle are increasingly recognized as a major challenge to human development (1). Nitrogen availability is a major limiting factor for crop growth, such that nitrogen cycles drive agricultural productivity. Specialised bacteria and archaea, known as diazotrophs, have evolved the capability to fix atmospheric nitrogen to $\mathrm{NH}_{3}$ before assimilating it for use in biological processes, using a series of nitrogen fixation ( $n$ if) genes (2). Biological nitrogen fixation is an important part of the nitrogen cycle, as it replenishes the nitrogen content of the biosphere. Nitrogen fixation is accomplished by the highly conserved Adenosine triphosphate (ATP)-hydrolysing and redox-active nitrogenase enzyme complex(3). Klebsiella oxytoca (previously classed as K. pneumonia), a free-living diazotroph, has long been used as a model system for the study of $\mathrm{N}$ fixation. Nitrogenases are composed of a reductase (Fe protein) and a catalytic component (MoFe protein). The MoFe protein is a tetramer of NifD and NifK, carrying an iron-molybdenum cofactor (FeMo-co[MoFe ${ }_{7} \mathrm{~S}_{9}-\mathrm{C}-$ homocitrate]) in each NifD subunit and a P-cluster ([8Fe-7S] cluster) at each NifD-NifK interface. NifH forms the dimeric Fe protein, with a [4Fe-4S] cluster in the subunit interface (4). Most nif gene products are involved in the assembly, function and regulation of the biochemically complex nitrogenase. In $K$. oxytoca, nif genes organised into 7 operons, enabling co-ordinated expression (5). The assembly of active nitrogenase requires the Nif proteins to function together either in series or in tandem. The NifU/NifS machinery is sufficient to provide [4Fe-4S] for NifH biogenesis. NifDH, however, requires many Nif proteins for biosynthesis of the structurally complex FeMo-co. NifU/NifS generate the NifB cofactor by providing [Fe-S] cluster substrates, which are transferred to NifEN. Fe, Mo, and homocitrate are incorporated into FeMo-co by NifQ, NifH, NifV, NifT and NifX. The completed FeMoco is incorporated into apo-NifDK via NifY to yield holo-NifDK (8). An overview of nif genes and their functions in Klebsiella oxytoca is provided in table 1.

\begin{tabular}{|c|c|}
\hline Gene & Identity and/or role of gene product \\
\hline \multicolumn{2}{|l|}{ Structural } \\
\hline nifH & $\begin{array}{l}\text { Fe protein, a homodimer of nitrogenase. NifH is an obligate electron donor to } \\
\text { the MoFe protein and is required for FeMo-co biosynthesis as well as apo-MoFe } \\
\text { protein maturation. }\end{array}$ \\
\hline nifD & $\begin{array}{l}\alpha \text { chain of the MoFe protein, an } \alpha 2 \beta 2 \text { tetramer of nitrogenase. Substrate } \\
\text { reduction at FeMo-co occurs within the } \alpha \text { subunit. }\end{array}$ \\
\hline nifk & $\beta$ chain of the MoFe protein. $P$ clusters are present at the $\alpha \beta$ interfaces. \\
\hline nifJ & $\begin{array}{l}\text { Pyruvate:flavodoxin (ferrodoxin) oxidoreductase. Electron donor to the Fe } \\
\text { protein, provided by oxidative decarboxylation of pyruvate to acetyl-CoA. }\end{array}$ \\
\hline nifF & Flaxodoxin. Electron donor to the Fe protein. \\
\hline \multicolumn{2}{|l|}{ Regulatory } \\
\hline nifA & $\sigma^{54}$-dependent activator of nif gene transcription. Co-transcribed with nifL. \\
\hline
\end{tabular}


nifL nif gene negative regulator. Senses redox and fixed nitrogen status to regulate nitrogen fixation by modulating activity of NifA.

\section{Cluster} Biosynthesis

nifQ Involved in FeMo-co biosynthesis. Proposed to function in early $\mathrm{MoO}_{4}{ }^{-2}$ processing.

nifB Involved in FeMo-co biosynthesis. NifB-co is a specific Fe and S donor to FeMo$\mathrm{co}$, and is transferred to the NifEN complex where it is processed to FeMo-co.

nifN Involved in FeMo-co biosynthesis. Forms an $\alpha 2 \beta 2$ tetramer with NifE which has been proposed to act as a scaffold upon which FeMo-co is built and then inserted into the MoFe protein.

nifE As above.

nifV Homocitrate synthase. Involved in FeMo-co biosynthesis although exact role remains unknown.

nifS Cysteine desulphurase. Involved in FeS (both [8Fe-7S] and [4Fe-4S]) cluster biosynthesis and repair by mobilization of $\mathrm{S}$.

nifZ Involved in MoFe protein maturation. Suggested to be specifically required for the formation of the second P-cluster.

nifU Involved in FeS cluster biosynthesis. Homodimer of two subunits each containing a $2 \mathrm{Fe}-2 \mathrm{~S}$ cluster, proposed to have a redox function involving release of Fe for FeS cluster biosynthesis.

\begin{tabular}{|c|c|}
\hline nifX & $\begin{array}{l}\text { Involved in FeMo-co biosynthesis. Appears to be associated with mature FeMo- } \\
\text { co and accumulates an FeSMo-containing precursor. }\end{array}$ \\
\hline nift & Involved in FeMo-co biosynthesis. Exact role remains unknown. \\
\hline \multicolumn{2}{|l|}{ Processing } \\
\hline nifM & Accessory protein for $\mathrm{NifH}$, required for $\mathrm{NifH}$ maturation. \\
\hline nifY & Chaperone for the apo-MoFe protein. \\
\hline \multicolumn{2}{|l|}{ Other } \\
\hline nifW & $\begin{array}{l}\text { Proposed to be involved in maturation or stability of the MoFe protein. Other } \\
\text { studies have proposed a role in protection of MoFe protein from oxygen } \\
\text { damage. }\end{array}$ \\
\hline
\end{tabular}

Table 1: Nif genes of Klebsiella oxytoca M5a1 and their functions.

In diazotrophic proteobacteria, such as $K$. oxytoca, the two-component system NtrB-NtrC couples N limitation to a global transcription response upon $\mathrm{NtrC}$ phosphorylation (13). The level of phosphorylated $\mathrm{NtrC}$ controls the $\sigma^{54}$-dependent transcription of many genes associated with nitrogen assimilation, in addition to those encoding key regulators of nif gene cluster expression, nifL and nifA. NifA initiates transcription of the remaining six nif operons via $\sigma^{54}$-dependent promoters. However, NifA activity is repressed upon interaction with NifL in conditions unsuitable for nitrogen fixation, such as oxygen and increased fixed $\mathrm{N}(6)$. $\mathrm{N}$ status regulates nif gene expression at both the transcriptional (via $\mathrm{NtrC}$ ) and post-translational (via NifL) levels. Post-translational modifications play a key role in rapidly fine-tuning the $\mathrm{N}$ fixation and assimilation pathways in response to internal $\mathrm{N}$ status, specifically glutamine concentration (14). The PII-like proteins GInK and GInB are covalently modified 
by the uridylytransferase (UTase) GlnD in response to low glutamine. In contrast, glutamine stimulates the uridylyl-removing (UR) activity of GlnD. By modulating the NifA-NifL interaction, GlnK is responsible for additional $\mathrm{N}$-dependent regulation of nif gene expression (9). The NifL-NifA interaction is inhibited merely by the presence of GlnK, irrespective of uridylation status. However, covalent modification of GInK becomes important in its interaction with the membrane-associated ammonium transporter AmtB. The de-uridylation of GInK in response to increased nitrogen allows for membrane sequestration of GlnK by AmtB, decreasing its cytoplasmic concentration for modulation of NifL-NifA interaction (16). The other PII-like protein GlnB modulates the kinase/phosphatase activities of NtrB upon direct sensing of glutamine, but only when de-uridylated (6).

Advances in multiple reaction monitoring mass spectroscopy MRM-MS are applied to quantify targeted proteins in complex biological samples with high sensitivity. Triple quadrupole mass spectrometers are best suited for protein absolute standard quantification, where the three chambers $(\mathrm{Q} 1, \mathrm{Q} 2, \mathrm{Q} 3)$ can be set to act as mass filter, collision chamber and fragment ion detector and selected precursor-fragment ion pairs (termed transitions) can be measured directly. Quantitative proteomics commonly involve the addition of labelled standards to biological samples, against which the protein of interests can be measured in the mass spectrometer. MRM-MS is both extremely sensitive, detecting peptides down to the attomole range, and extremely selective. While label-free quantitative approaches can measure hundreds of proteins simultaneously, the availability of labelled standards has several advantages with regards to accuracy, precision, reproducibility and stoichiometry (reviewed 6).

The addition of isotopically labelled standards of known concentration to the sample of interest allows the absolute quantification of targeted sample proteins in MRM-MS. Various isotopically labelled peptidic standard approaches have been used for absolute protein quantification: i) protein standard absolute quantification (PSAQ), where the protein to be measured is purified and isotopically labelled (7); ii) AQUA (absolute quantification) involves the addition of labelled peptides to be measured and iii) QconCATs are artificial proteins encoding a concatemer of tryptic peptides specific to a protein set of interest in a single open reading frame facilitates multiplexed protein quantification $(24,25)$. The choice of which labelled standard approach is commonly guided by how many proteins are targeted (6). In the 10-50 target protein range, QconCAT fares best, and was adopted here to quantify the 20 Nif proteins. These peptides must be 'quantotypic', in that they are unique to the protein under study and suitable for quantification (26). Endoproteolytic fragmentation of the QconCAT-analyte mix results in release of QconCAT peptides in a strict 1:1 ratio, which can serve as internal control during analysis. To further improved the QconCAT methodology, we increased trypsin digestion 
reproducibility between target and standard proteins by introducing target amino acids $\mathrm{N}$-terminal to the trypsin cleavage site. For the determination of intracellular protein concentrations we optimised sample preparation and measurements in order to increase reproducibility across biological samples. For the results shown in table two of the main document, standard errors of the mean across three biological replicates ranged from $0.8 \%$ to $13 \%$, demonstrating high robustness of the workflow.

\section{Materials and Methods}

QconCAT design: In silico trypsin digestion of annotated $K$. oxytoca M5a1 Nif protein sequences, obtained from NCBI accession code AMPJ00000000, and peptide uniqueness analysis were undertaken in Skyline (10). For identification of quantotypic peptide candidates, the Skyline-generated transition list was exported and run against Nif protein-containing $K$. oxytoca M5a1 protein extract prepared as outlined below. Final peptide selection was based on the following favourable characteristics: absence of Cys and Met, absence of His, presence of Pro, Pro not adjacent to cleavage site, lack of residues with possible artefactual modification (Glu, Trp, Asn, N-terminal Gln, adjacent Lys/Arg/His at either terminus), favourable peak characteristics (multiple co-eluting transitions, symmetrical peak $(11,12,13)$. Lastly, peptides were chosen by retention time to maximize peak separation. Initial control for peptide identity was done by comparing against a control $K$. oxytoca M5a1 protein extract expected to not contain any Nif proteins (aerobic, $\Delta n i f L A)$. An Enhanced Product Ion (EPI) scan was used to confirm peptide identity. Known tryptic peptides from Bovine Serum Albumin (BSA) identified from previous Multiple Reaction Monitoring MS (MRM-MS) experiments were selected based on retention time and placed on the $3^{\prime}$ and $5^{\prime}$ end of each QconCAT, to act as internal controls against potential degradation by exoproteolysis (13). Each QconCAT was commercially synthesized (GeneArt, Life Technologies). A final transition list was exported from Skyline and used for all subsequent analyses (Appendix I).

Growth of K. oxytoca under anaerobic conditions: Single colonies of wild-type (WT) K. oxytoca M5a1 and $K$. oxytoca M5a1 $\triangle$ nifLA were used to inoculate a $2 \mathrm{ml}$ preculture in Luria-Bertani (LB) media (5 g/l $\mathrm{NaCl}, 5 \mathrm{~g} / \mathrm{l}$ yeast extract, $10 \mathrm{~g} / \mathrm{l}$ tryptone). Cells were grown at $30{ }^{\circ} \mathrm{C}$ at $200 \mathrm{RPM}$ until reaching a suitable density, and $10 \mathrm{ml}$ overnight cultures set up in NFDM media ( $2 \mathrm{ml}$ 5X NFDM [100 g/l glucose, $2 \mathrm{mM} \mathrm{MgSO}_{4}, 0.5 \mathrm{mM} \mathrm{Na}_{2} \mathrm{MoO}_{4}, 0.45 \mathrm{mM} \mathrm{FeSO}_{4}, 125 \mathrm{mM} \mathrm{KH}_{2} \mathrm{PO}_{4}, 350 \mathrm{mM} \mathrm{K}_{2} \mathrm{HPO}_{4}$ ], $200 \mu \mathrm{ll} \mathrm{M} \mathrm{NH}_{4} \mathrm{Cl}$ ) with $25 \mu \mathrm{l} \mathrm{WT}$ or $50 \mu \mathrm{l} \Delta$ nifLA cell suspension, and grown at $30^{\circ} \mathrm{C}$ overnight. 
Cultures were centrifuged at $4000 \mathrm{~g}$ and pellet washed with 1X NFDM to remove residual ammonia. Cells were resuspended in $10 \mathrm{ml} 1 \mathrm{X}$ NFDM and kept on ice to temporarily inhibit cell growth. The $\mathrm{OD}_{600}$ of re-suspended cultures was measured using a SpectroStar Nano microplate reader (BMG LABTECH) and normalised volumes of each culture were added to $40 \mathrm{ml}$ cold NFDM media (as above, scaled up) in sealable glass culture vessels for a final $\mathrm{OD}_{600}$ of 0.1 . WT $K$. oxytoca M5a1 was grown in both 10 (Nrich) and 0.25 (N-poor) $\mathrm{mM} \mathrm{NH}_{4} \mathrm{Cl}$, and $\triangle$ nifLA (mutant) in $0.25 \mathrm{mM} \mathrm{NH}_{4} \mathrm{Cl}$. Vessels were fixed with airtight caps and sparged with filter-sterilised $\mathrm{N}_{2}$ for at least 25 minutes. One vessel was checked for absence of oxygen using $02 x^{x} \operatorname{Dot}^{\circledR}$ technology (OxySense). Finally, $1 \mathrm{ml}$ of pure acetylene was added before the vessels were warned to $25^{\circ} \mathrm{C}$. $\mathrm{OD}_{600}$ and $\mathrm{NH}_{4}$ concentration were measured regularly in all cultures by sampling $0.4 \mathrm{ml}$ using a $\mathrm{N}$-sparged $1 \mathrm{ml}$ syringe. $\mathrm{OD}_{600}$ was measured as described above following a $1 / 4$ dilution of culture. Supernatant for $\mathrm{NH}_{4}$ assay was obtained by centrifugation, as above, of $150 \mu \mathrm{l}$ culture and storing at $4{ }^{\circ} \mathrm{C}$. Acetylene reduction by gas chromatography-MS (GC-MS) was checked at $\mathrm{t}=4,8.5$ and 10 hours (Appendix IV). Early and late $\mathrm{N}$-fixing transition samples were taken according to results, at $t=5$ and $t=10.15 \mathrm{ml}$ of the cell suspension was sampled and centrifuged for 25 minutes at $4000 \mathrm{~g}$ before cell pellets were frozen at $-80^{\circ} \mathrm{C}$. [ $\left[\mathrm{NH}_{4}\right]$ was assayed the next day using the Ammonium Test (Merck Millipore) and a standard curve $\left(R^{2}=0.99\right.$ [to 2 decimal places]) of duplicates of 10 to $0 \mathrm{mM} \mathrm{NH}_{4}$ in culture media.

QconCAT expression and purification: Designed QconCATs were received from Life Technologies in a pET100/D-TOPO vector with a 5' hexa-histidine tag, an ampicillin resistance gene, and a lacO operator. Transformation of $\mathrm{CaCl}_{2}$-chemically competent $E$. coli $\mathrm{BL} 21 \Delta / y s$, arg cells was undertaken according to standard protocols before plating on LB agar $100 \mu \mathrm{g} / \mathrm{ml}$ ampicillin-selection plates. Each QconCAT was expressed in ${ }^{13} \mathrm{C}_{6}{ }^{15} \mathrm{~N}_{4}$ arginine and ${ }^{13} \mathrm{C}_{6}{ }^{15} \mathrm{~N}_{2}$ lysine-labelled expression media (1X Gutnick media [33.79 $\left.\mathrm{mM} \mathrm{KH}_{2} \mathrm{PO}_{4}, 77.51 \mathrm{mM} \mathrm{K}_{2} \mathrm{HPO}_{4}, 5.74 \mathrm{mM} \mathrm{K}_{2} \mathrm{SO}_{4}, 0.41 \mathrm{mM} \mathrm{MgSO}_{4} \cdot 7 \mathrm{H}_{2} \mathrm{O}\right], 0.4 \%$ glucose, $10 \mathrm{mM} \mathrm{NH}_{4} \mathrm{Cl}$, $1 \mathrm{mM}$ of each amino acid, $1 \mathrm{X}$ HoLe trace elements) (Appendix II). Overnight cultures were inoculated by adding one colony from each QconCAT plate to $10 \mathrm{ml}$ labelled media with $100 \mathrm{\mu l} / \mathrm{ml}$ ampicillin, and were incubated with shaking at $37^{\circ} \mathrm{C} .2 \mathrm{ml}$ of the overnight culture was added to $100 \mathrm{ml}$ pre-warmed labelled media. Day cultures were grown to an $\mathrm{OD}_{600}$ of $0.4-0.6$ at $37^{\circ} \mathrm{C}$ with shaking, at which point 1 $\mathrm{ml}$ uninduced cell sample was removed. Cells were induced by adding isopropyl $\beta$-D-1thiogalactopyranoside (IPTG) to a final concentration of $1 \mathrm{mM}$ and incubated for 4 hours at $37^{\circ} \mathrm{C}$ with shaking. $1 \mathrm{ml}$ of each induced culture was removed, and cultures were centrifuged for 20 minutes at $4000 \mathrm{~g}$ before storing at $-80^{\circ} \mathrm{C}$. Induced and uninduced cell samples were centrifuged at $4000 \mathrm{~g}$ for 5 minutes before storing pellet at $-80^{\circ} \mathrm{C}$. 
The pellet was resuspended in $20 \mathrm{ml} 20 \mathrm{mM}$ Tris- $\mathrm{HCl}$ (pH 8.0) before pulsed sonication ( 2 seconds on, 2 seconds off, $40 \%$ amplitude) for 1 hour on ice. The broken cell suspension was centrifuged at $4{ }^{\circ} \mathrm{C}$ for 45 minutes at $27000 \mathrm{~g}, 8 \mu \mathrm{l}$ of the supernatant aliquoted for sodium dodecyl sulphate polyacrylamide gel electrophoresis (SDS-PAGE) and stored at $-80^{\circ} \mathrm{C}$. The pellet was resuspended in 20 $\mathrm{ml} 20 \mathrm{mM}$ Tris- $\mathrm{HCl}$ with $7 \mathrm{M}$ urea. The suspension was centrifuged as before and supernatant aliquoted.

$4 \mathrm{ml}$ new Ni-NTA resin per purification was prepared by a series of centrifugation $\left(4{ }^{\circ} \mathrm{C}, 4000 \mathrm{~g}, 5\right.$ minutes) and wash (4 ml water, $4 \mathrm{ml}$ binding buffer [95 mM Na $2 \mathrm{HPO}_{4}, 5.2 \mathrm{mM} \mathrm{NaH}_{2} \mathrm{PO}_{4}, 50 \mathrm{mM} \mathrm{NaCl}$, $3 \mathrm{M}$ urea]) steps. $9 \mathrm{ml}$ of the QconCAT-containing supernatant was added to the resin and incubated at room temperature for 45 minutes with gentle shaking. The mix was added to a purification column and flow-through collected. Buffers were added sequentially and flow-through collected: $25 \mathrm{ml}$ binding buffer, $15 \mathrm{ml}$ wash buffer (binding buffer $+30 \mathrm{mM}$ Imidazole), $2 \mathrm{ml}$ elution buffer (binding buffer $+500 \mathrm{mM}$ Imidazole). $8 \mu$ l aliquots of each flow-through were collected for SDS-PAGE. The elution was dialysed in 12-15 kDa molecular weight cut off dialysis tubing in dialysis buffer (1X Gutnick, $7 \mathrm{M}$ urea) overnight at $4{ }^{\circ} \mathrm{C}$ with stirring. Dialysis buffer was replaced and sample dialysed for at least 1 additional hour. $1 \mathrm{mM}$ tris(2-chloroethyl) phosphate (TCEP) was added and the purified QconCAT stored at $-80^{\circ} \mathrm{C}$.

SDS-PAGE: $15 \%$ acrylamide SDS-PAGE gels were prepared and run according to the Laemmli method. $4 \mu \mathrm{l}$ 3X Instant-Bands Sample Treatment Buffer (EZ Biolab) was added to $8 \mu \mathrm{l}$ sample before incubation at $95{ }^{\circ} \mathrm{C}$ for 5-10 minutes. $10 \mu \mathrm{l}$ of samples was run against $3 \mu \mathrm{l}$ of the EZ-Ladder Fluorescent Protein Molecular Weight Markers (EZ Biolab) at 200 V for 60 minutes. The gel was visualized under ultraviolet (UV) light using a Gel Doc 2000 (BIO RAD). For the induced and uninduced cell samples, $100 \mu \mathrm{l} 2 \mathrm{X}$ Laemmli buffer (4 \% SDS, 20 \% glycerol, $120 \mathrm{mM}$ Tris-HCl [pH 6.8], $0.02 \%$ bromophenol blue) and $1 \mu \mathrm{l}$ pure $\beta$-mercaptoethanol were added, before incubation at $95{ }^{\circ} \mathrm{C}$ for 5 minutes. Samples were centrifuged for 10 minutes at $14000 \mathrm{~g}$, and $10 \mu \mathrm{l}$ run against $5 \mu \mathrm{l}$ PageRuler Prestained Protein Ladder (ThermoFisher Scientific) as above. Gel was stained with Coomassie-based SimplyBlue SafeStain (ThermoFisher Scientific). Concentration of the QconCATs was established by a detergent compatible (DC) Assay (BioRad) according to the manufacturers protocol. A standard curve $\left(R^{2}=1.00\right)$ with 9 concentrations ranging from 0 to $2 \mathrm{mg} / \mathrm{ml} \mathrm{BSA}$ in duplicates was used.

MRM-MS sample preparation: The sample pellets were resuspended in $1 \mathrm{ml} 1 \mathrm{X}$ Gutnick with $7 \mathrm{M}$ urea before sonication for 10 minutes on ice as before. Sample was centrifuged at $15000 \mathrm{~g}$ and $4{ }^{\circ} \mathrm{C}$ for 45 
minutes. DC assays were undertaken on protein-containing supernatant as above. Trypsin digestion reactions were set up as follows: $30 \mu \mathrm{l}$ protein extract, $3 \mu \mathrm{l}$ of each QconCAT at appropriate dilution (see figure 7c), $3 \mu \mathrm{l} 100 \mathrm{mM}$ TCEP, $50 \mathrm{mM} \mathrm{NH}_{4} \mathrm{CO}_{3}$ up to total of $290 \mu \mathrm{l}$. An $8 \mu$ l pre-digestion sample was taken. $5 \mu$ trypsin at $0.4 \mathrm{mg} / \mu \mathrm{l}$ was added and the reaction incubated at $37^{\circ} \mathrm{C}$ for 4 hours, before incubation at room temperature overnight. An $8 \mu \mathrm{l}$ post-digestion aliquot was taken and $15 \mu \mathrm{l}$ pure formic acid (5\%) added. Samples were centrifuged at $15000 \mathrm{~g}$ prior to pipetting into liquid chromatography (LC) vial.

QconCAT validation: All MRM-MS results were viewed and analysed on Skyline, and quantification based on integrated peak area. Manual integration of all peaks was undertaken, such that (a) the correct peak corresponding to the tryptic peptide was selected and (b) integration boundaries defined the area between points where the curve first touches the $x$-axis. Manual integration was adjusted if Skyline-calculated background was $>5 \%$ of total peak area. The $\triangle$ nifLA and WT N-poor samples at $\mathrm{t}=$ 10 were used to vary the $\%$ Nif protein in the Nif protein signal linearity assay. After adjusting samples to the same total protein concentration, samples were mixed such that Nif protein-containing sample constituted $100,50,10,1,0.1,0.01$ and $0.001 \%$ of the protein extract. Linearity of High QconCAT signal was assayed by preparing a dilution series such that QconCAT concentration added to the trypsin digestion reaction was $2,1,0.2,0.04,0.008,0.0016$ times stock concentration. Trypsin digestion was set up as above and samples run with final QconCAT transition list (Appendix I). Data analysis using Skyline was undertaken as described, and absolute quantification values obtained from standard:sample ratio and known concentration of isotope-labelled QconCAT. Quantification as copies per cell was derived from $\mathrm{OD}_{600}$ (supplementary file).

Mass Spectroscopy: For quantification, detection of the compounds was based on MRM-MS. Samples (typically $40 \mu \mathrm{l}$ ) were analysed by triple quadrupole HPLC-electrospray ionisation/MS-MS using a Shimadzu Prominence UPLC coupled to an Applied Biosystems Q-TRAP 6500 (AB SCIEX, Massachussetts, USA). Chromatographic separation was carried out by reverse phase chromatography on a Phenomenex Luna C18(2) 100A ( $3 \mu \mathrm{m}, 100$ by $2 \mathrm{~mm}$ ) HPLC column, at $50^{\circ} \mathrm{C}$. A gradient system using $\mathrm{A}$ ( $5 \% \mathrm{CH}_{3} \mathrm{CN}, 94.9 \% \mathrm{H}_{2} \mathrm{O}, 0.1 \%$ formic acid) and $\mathrm{B}\left(5 \% \mathrm{H}_{2} \mathrm{O}, 94.9 \% \mathrm{CH}_{3} \mathrm{CN}, 0.1 \%\right.$ formic acid) was used, with solvent flow rate of $250 \mu \mathrm{l} /$ minute. A linear gradient from $0 \%$ B to $25 \%$ B over 30 minutes was followed by an increase to $50 \%$ B over the next 5 minutes. $B$ was then increased to 100 $\%$ over the next 2 minutes and held at $100 \%$ for 5 minutes, before return to initial conditions. The MS was operated in the positive mode using an lonDrive ${ }^{\mathrm{TM}}$ Turbo $V$ as the ion source. Source conditions were: temperature, $500{ }^{\circ} \mathrm{C}$; ion source gas $1,40 \mathrm{psi}$; ion source gas $2,60 \mathrm{psi}$; ion spray voltage, 5500 
V; curtain gas, 40 psi; CAD gas setting, -2. An Enhanced Scheduled MRM method was used for the analysis, and details of the full method can be found in appendix I. For qualitative peptide validation, the MS was run in 'trap' mode for an Enhanced Product Ion (EPI) scan using the same source conditions. An information dependent acquisition (IDA) method was carried out based on (29). For qualitative peptide validation, the MS was run in 'trap' mode for an Enhanced Product lon (EPI) scan using the same source conditions. An information dependent acquisition (IDA) method was carried out based on (14).

\section{Results}

\section{Growth and $N$ fixing profiles of N-poor, $N$-rich and mutant $K$. oxytoca strains}

To establish growth conditions for $K$. oxytoca M5a1 and $K$. oxytoca M5a1 $\Delta$ nifLA (mutant), cells were grown in NFDM medium under anaerobic conditions over a time course of 9.5 hours, were growth and $\mathrm{N}$ fixing parameters were monitored hourly. The concentration of $\mathrm{NH}_{4}$ in the $\mathrm{N}$-rich sample steadily decreased over the course of 9.5 hours. In the case of both the mutant and N-poor cultures, $\left[\mathrm{NH}_{4}\right]$ decreases steadily until $\mathrm{t}=2$, at which point it runs out (Figure 1 ). Acetylene reduction was observed only in the WT N-poor culture, from at least 4 hours after $\mathrm{N}$-sparging (Figure 4c). Samples at 5 and 10 hours were deemd early and later $\mathrm{N}$ fixation states in $K$. oxytoca.
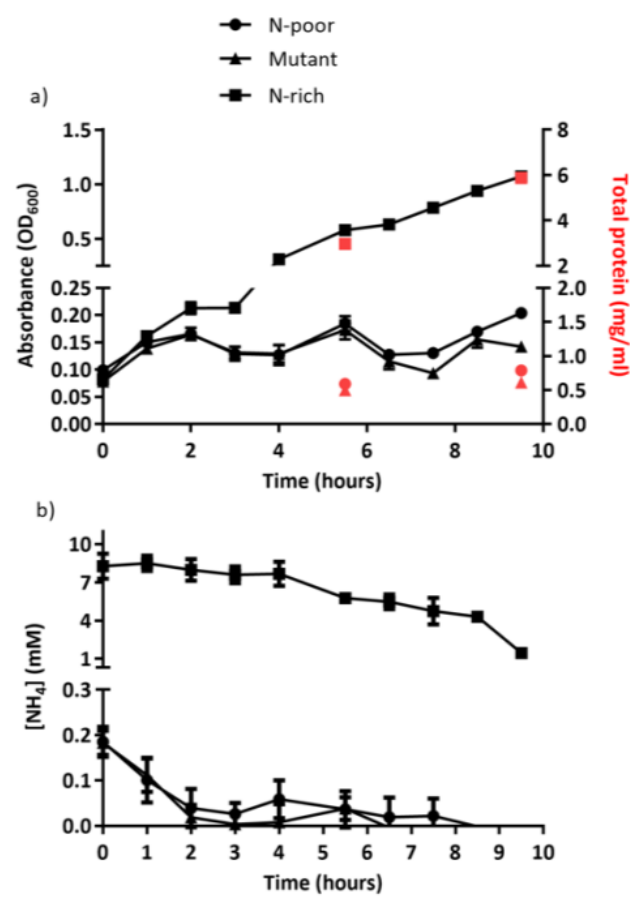


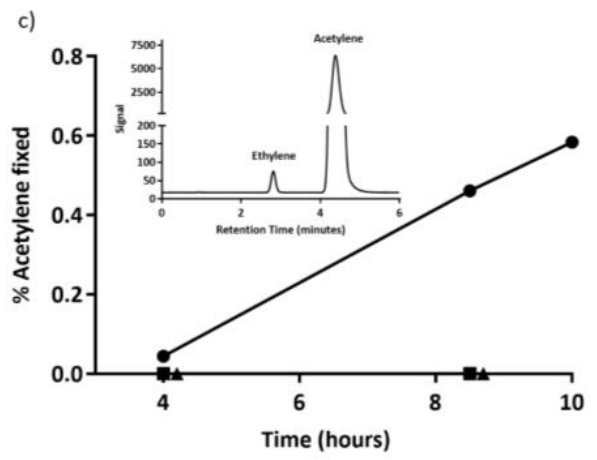

Figure 1: Growth and nitrogen fixation of $K$. oxytoca M5a1 grown in 0.25 (N-poor) and 10 (N-rich) $\mathrm{mM} \mathrm{NH}_{4}$, and $K$. oxytoca M5a1 $\Delta$ nifLA (mutant) grown in $0.25 \mathrm{mM} \mathrm{NH}_{4}$, all under anaerobic conditions. (a) Growth profiles of $\mathrm{N}$-poor, $\mathrm{N}$-rich and mutant cultures in terms of absorbance $\left(\mathrm{OD}_{600}\right)$ from 0 to 9.5 hours after $\mathrm{N}$ sparging. (b) Ammonium concentration of the supernatant of each culture was measured by the Merck Millipore Ammonium test. In (a) and (b), error bars represent the Standard Error of the Mean (SEM) over three biological replicates. (c) One replicate of each culture was tested for $\mathrm{N}$ fixation by conversion of acetylene to ethylene at $\mathrm{t}$ $=4,8.5$ and 10 hours after $\mathrm{N}$ sparging. \% acetylene conversion was calculated by peak area changes in GC-MS results. Inset is the GC-MS result obtained at $t=10$ hours for the $\mathrm{N}$-poor sample showing the expected appearance of an ethylene peak at approximately 2.5 minutes. Error was not calculated for (c) as only one sample was taken at each time point. Points representing \% acetylene for the mutant are offset by 0.25 for clearer presentation. Note that in (a), (b) and (c) inset the $y$-axis is split.

\section{QconCAT design and expression}

Three QconCATs containing selected tryptic peptides from all Nif proteins. Nif proteins were grouped according to approximate intensity of corresponding MRM-MS spectra in samples. Since trypsin interacts with 3 to 4 residues around the scissile bond (15), each peptide was flanked with sequences of 3 amino acids on either side of the cleavage site, leading to 6 amino acid 'linkers', to ensure quantitative trypsin cleavage. ExPASy PeptideCutter (16) was used to confirm trypsin digestion efficiency at the cleavage sites within the native protein sequence and the QconCATs to be the same. After overexpression in E. coli BL21 1 /ys, arg, each QconCAT was purified using Ni-affinity chromatography. Overexpression, molecular mass and urea solubilisation of Low, Medium and High QconCAT protein products were confirmed by SDS-PAGE $(36.4,37.6$ and $29.7 \mathrm{kDa}$, respectively, (supplementary file). Table 2 shows the complete peptide list of the 3 QconCats.

$\begin{array}{llcc}\text { Protein } & \text { LINKER.PEPTIDE.LINKER } & \text { QconCAT } & \text { Retention Time (minutes) } \\ \text { NifD } & \text { GSK.GVVFGPIK.DMA } & \text { High } & 14.95 \\ & \text { SSK.ALDKPVIPVR.CEG } & \text { High } & 11.67 \\ & \text { FVK.ALKPDLIGSGIK.EKY } & \text { High } & 13.52 \\ \text { NifH } & \text { STR.LILHAK.AQN } & \text { High } & 3.65 \\ & \text { VPR.DNIVQR.AEI } & \text { High } & 3.07 \\ \text { NifK } & \text { FQR.EALTVDPAK.ACQ } & \text { High } & 9.01\end{array}$




\begin{tabular}{|c|c|c|c|}
\hline & KGK.AFEVPLIR.LGF & High & 20.70 \\
\hline & LIR.LGFPLFDR.HHL & High & 23.98 \\
\hline \multirow[t]{2}{*}{ NifJ } & GKK.NLFGQPVR.LMEX & High & 12.43 \\
\hline & YAR.LITQLFGDR.MLI ${ }^{X}$ & High & 19.43 \\
\hline \multirow[t]{2}{*}{ NifB } & SGR.EAGEILIAR.QLE & High & 12.88 \\
\hline & TFR.TLELIR.EQL & High & 13.49 \\
\hline \multirow[t]{2}{*}{ NifF } & KGK.TVALFGLGDQR.GYP & High & 19.97 \\
\hline & IHK.QLGELADAPVNINR.TTL ${ }^{\mathrm{X}}$ & High & 17.91 \\
\hline NifD & TIR.ANAEAVIAR.YEGX & Medium & 7.12 \\
\hline \multirow[t]{2}{*}{ NifT } & AER.WGGAISLEGGR.RYYR,X & Medium & 15.01 \\
\hline & RER.GADLYAYIAK.QDL ${ }^{R}$ & Medium & 17.61 \\
\hline \multirow[t]{3}{*}{ NifE } & GRK.ALLYTGGVK.SWSR & Medium & 12.25 \\
\hline & NAR.TLLDVVYR.YQA & Medium & 19.38 \\
\hline & KAR.LPFLDINQER.EHA ${ }^{X}$ & Medium & 21.24 \\
\hline \multirow[t]{2}{*}{ NifM } & ASR.DAFAPLAQR.HSH & Medium & 14.07 \\
\hline & HAR.LELAFADIAR.QAP & Medium & 22.70 \\
\hline \multirow[t]{3}{*}{ NifN } & SLR.QLPVER.VVPX & Medium & 5.53 \\
\hline & HAR.DLAEQFALPLVR.AGF ${ }^{\mathrm{X}}$ & Medium & 27.90 \\
\hline & GMR.DTLFELANLIR.ERH ${ }^{\mathrm{X}}$ & Medium & 32.01 \\
\hline \multirow[t]{2}{*}{ NifS } & QFR.AALSPR.VAL & Medium & 2.21 \\
\hline & VGK.IPIAVGQTR.IDM ${ }^{X}$ & Medium & 10.77 \\
\hline \multirow[t]{2}{*}{ NifX } & TPR.LVVYGVK.ADR & Medium & 11.02 \\
\hline & SMK.VAFASSDYR.HVD & Medium & 9.27 \\
\hline \multirow[t]{2}{*}{ NifY } & LNR.DNPLEER.VF*,x & Medium & 7.02 \\
\hline & AGR.LPPWLAK.RLN ${ }^{R, x}$ & Medium & 16.36 \\
\hline \multirow[t]{3}{*}{ NifA } & HEK.GAFTGAVR.QRK & Low & 6.83 \\
\hline & RQR.LIAALEK.AGW & Low & 9.92 \\
\hline & LER.SAVLSESGLIDR.DVI & Low & 15.83 \\
\hline \multirow[t]{2}{*}{ NifL } & NPR.LLASSQTPR.EIYX & Low & 6.24 \\
\hline & AGK.LLAAIR.ESL & Low & 10.48 \\
\hline \multirow[t]{3}{*}{ NifQ } & LRR.LWLLYHAGK.GSFR, X & Low & 16.40 \\
\hline & PLR.MGLSPR.DWQ ${ }^{M}$ & Low & 5.95 \\
\hline & RRR.LMAELNATR.EEE ${ }^{R, M}, x$ & Low & 14.07 \\
\hline \multirow[t]{2}{*}{ NifU } & ALR.AAIANFR.GESX & Low & 8.49 \\
\hline & KVK.DHFFNPR.NAR ${ }^{R, X}$ & Low & 16.32 \\
\hline \multirow[t]{3}{*}{ NifV } & CQR.VAEAAQR.AID ${ }^{\mathrm{X}}$ & Low & 10.56 \\
\hline & IRR.FAENWK.RSP ${ }^{R, x}$ & Low & 17.81 \\
\hline & ASR.ASGQTLR.AIA & Low & 3.57 \\
\hline \multirow[t]{2}{*}{ NifW } & KLR.AEVPLQNR.LED ${ }^{R, x}$ & Low & 6.74 \\
\hline & NDR.APWLLAR.RLL ${ }^{R, X}$ & Low & 15.57 \\
\hline \multirow[t]{2}{*}{ NifZ } & VRR.GSTGFVR.DWG ${ }^{R}$ & Low & 3.96 \\
\hline & WFR.VPVQAIALIEER.EE*,x & Low & 21.67 \\
\hline \multirow[t]{3}{*}{ BSA } & LVNELTEFAK $^{\mathrm{X}}$ & Low & 14.20 \\
\hline & LVTDLTK & All & 8.20 \\
\hline & QTALVELLK ${ }^{X}$ & $\begin{array}{l}\text { Medium, } \\
\text { High }\end{array}$ & 15.80 \\
\hline
\end{tabular}


Figure 2: Final selection of Nif protein and BSA tryptic peptides, incorporated into three QconCATs (Low, Medium, High) based on approximate expression levels. Peptides are listed in the order in which they appear in the QconCAT. The linker amino acids on either side of the peptide represent the 5' and 3' natural flanking amino acids of each peptide within the Nif protein sequence. Peptides present at either end of the protein, and which are not bounded by three amino acids, have the missing amino acid denoted by a star. $R$, ragged end; $M$, methionine; $X$, contains residues susceptible to chemical or biological modifications. Retention times based on MRM-MS results are indicated and were considered during QconCAT design.

\section{Workflow validation}

To establish the robustness of the QconCAT design expression pipeline prior to native Nif protein quantification, we interrogated general QconCAT LC and mass spectroscopic behaviour LC-MS (Appendix I), indicating that theoretical peptide selection yielded well resolved tryptic peptide spectra for each QconCAT (Figure 7a). We directly measured in vivo isotopic labelling efficiency following overexpression of QconCats in E. coli BL21 1 /ys, arg in mutant strains, which showed $100 \%$ labelling efficiency, excluding the possibility of potential unspecific transamination in cells lacking both the specific transaminases for lysine and arginine.

Nif protein tryptic peptides were organised into Low, Medium and High QconCATs based on peak intensity (and thereby expression levels) during QconCAT design. The differences in the intensities were about ten-fold. 10-fold dilutions of each QconCAT were therefore prepared in order to determine biologically relevant concentrations, and samples prepared with identical native Nif protein concentration using a previously prepared $\mathrm{N}$-fixing sample taken after 24 hours. The highest expressed Nif proteins were present at concentrations well above that of the undiluted High QconCAT (Figure c. I). Results for both the Medium and Low QconCATs (Figures c. II and III respectively), indicate that a 10-fold dilution of the QconCAT stock would lead to biologically relevant labelled Nif tryptic peptide concentrations.

\section{Validation of QconCAT-mediated quantification of Nif proteins by MRM-MS}

The QconCAT method yields analytically rigorous data, and thereby accurate and precise quantitative measurement, by providing an isotopologue of the target analyte as an internal standard, to correlate signal intensity and analyte amount. Therefore, changes in analyte concentration should lead to proportional changes in signal, and thus a linear relationship between the two. Linearity can be compromised if the true protein concentration is not within the detection limit of the machinery used, or if the QconCAT is not an accurate measure of Nif protein concentration. Such a result could be observed if, for instance, if trypsin digestion efficiencies of QconCAT and native Nif protein were not 
comparable. We confirmed that all samples yielded $>90 \%$ trypsin digestion efficiency via SDS PAGE sypro-ruby staining and gel imaging, as we have done before (7). Both the native Nif proteins and the QconCAT were subject to linearity analysis, with signal calculated in terms of peak area. We confirmed that samples yielded $>90 \%$ trypsin

Linearity of each QconCAT peptide standard was assayed within a complex bacterial matrix. The proportion of Nif protein (WT N-poor, 10 hours) in the matrix was varied from 100 to $0.001 \%$ and QconCATs added at a constant concentration. Signal saturation was not apparent for any of the transitions as the slope of the dilution curves are consistently linear until $100 \%$ Nif. All transitions for each peptide were assessed to determine the point below which the concentration to signal response ratio is no longer linear ('quantification limit'). After assessing all transitions (Figure 2a. I.), those which showed no linearity anywhere over the whole \% Nif range were removed (Figure 2a. II.) and were not included in further quantification analyses. Of the remaining transitions, linearity is broadly conserved in a 100 -fold range from 1 to $100 \%$ Nif protein, although the quantification limit of each transition, below which peak areas cannot be quantified with certainty, was noted for further analysis.

Conversely, QconCAT linearity within a constant bacterial protein matrix over a series of 2- and 5- fold dilutions was assayed. Most transitions for the High QconCAT were linear from a 0.1 to 2 dilution range (Figure 2b). 
a) I.

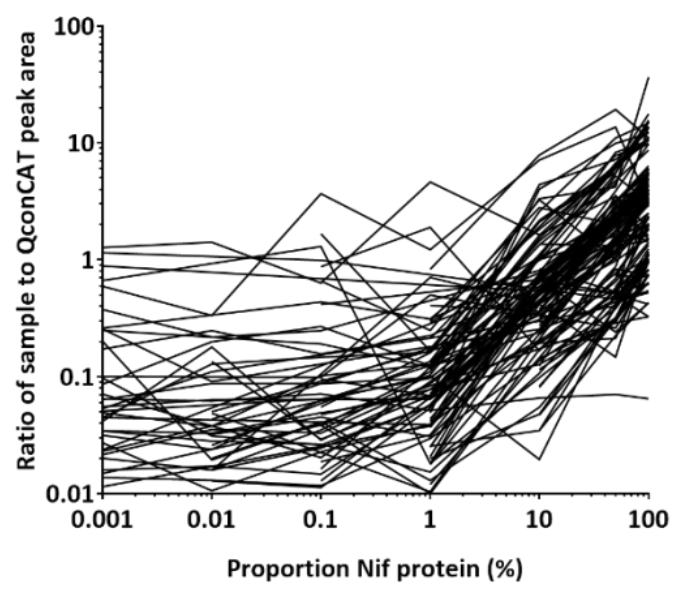

II.

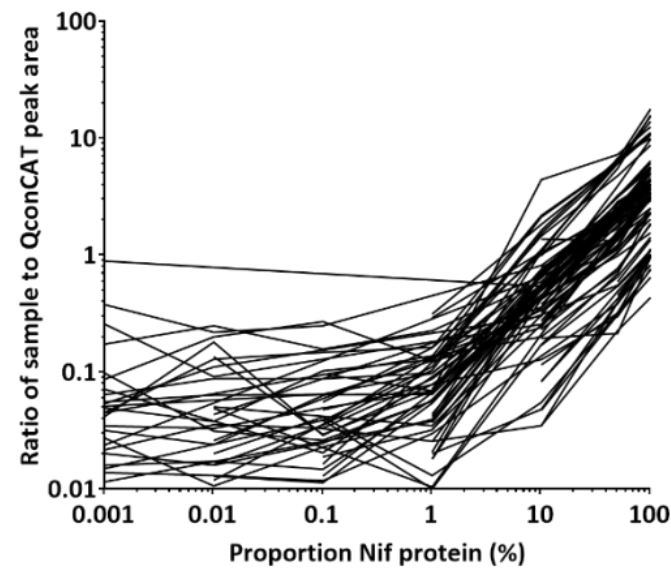

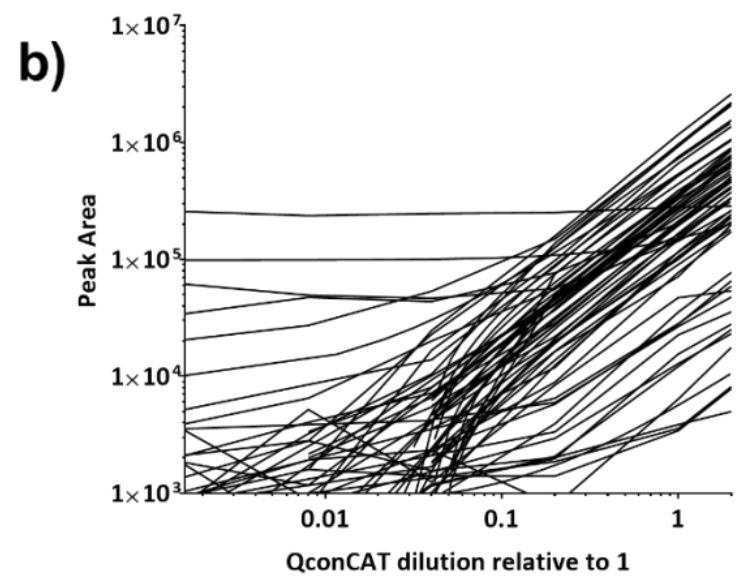

Figure 2: Validation of QconCAT-mediated quantification of Nif protein by MRM-MS. (a) A Nif proteincontaining sample dilution series was established in order to identify transitions reliably quantifiable (linear), and over what range (I.). Transitions which were not linear were removed (II.) and were not included in further analyses. Ratio of the peak area of each analyte peptide to the corresponding heavy QconCAT peptide were graphed on a logarithmic scale against \% Nif protein in the sample. (b) The High QconCAT was diluted and peak areas calculated to identify the linear, and thereby quantitative, range. All peak areas were calculated by Skyline as is outlined in Methods. 


\section{Absolute quantification of Nif proteins in N-rich, N-poor and mutant $\mathrm{K}$. oxytoca cultures}

Quantification based on MRM-MS of Nif proteins was undertaken at two time points, early $(t=5)$ and late $(t=10)$, across the transition to diazotrophic growth, in a N-poor, N-rich and mutant culture (Figure 1). Purified QconCATs were added to complex protein samples derived from a time course experiments. Trypsin digestion efficiency determined by SDS-PAGE (supplementary file). The extracted ion chromatograms for unlabelled sample and labelled quantotypic peptide released from the QconCAT were used to calculate the amount of analyte, as protein count per cell. Quantitatively robust peptides were used in the quantification of Nif proteins. The peak area corresponding to the limit of quantification for each transition identified was calculated in terms of protein count per cell. Transitions giving protein counts below the limit of quantification were not included in further quantification. In general, the N-rich and mutant cultures were effective controls. The expression of some nif genes in the $\mathrm{N}$-rich samples could be expected. The $\Delta$ nifLA strain should not express the NifL and NifA regulatory proteins, and hence should be nif-. However, some transitions corresponding to Nif protein tryptic peptides were visible in MRM-MS. Of these, however, the majority are below the limit set for quantitative accuracy, and the absence of other co-eluting transitions for the same peptide means their significance is questionable. Figure 3 shows the protein copy number per cell for the most highly abundant proteins ( $N$ if $H, D, K$ ) and lowest abundance proteins (Nif J, F L, A). Abundances of all other twelve quantified proteins are shown in the supplementary file. 
NifK

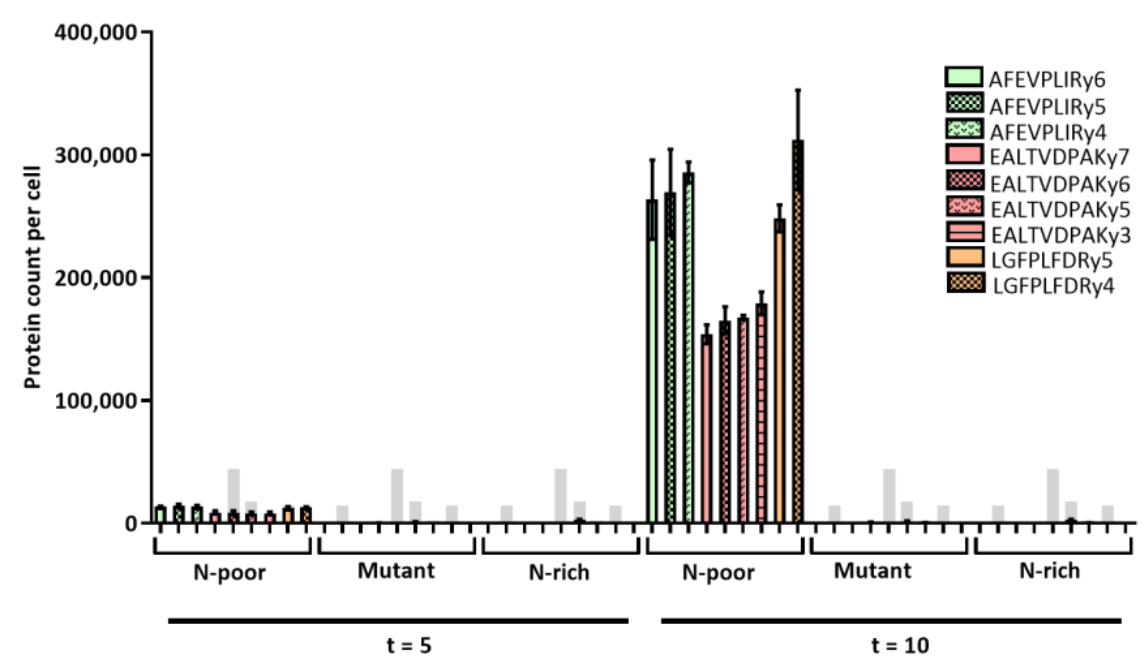

NifD

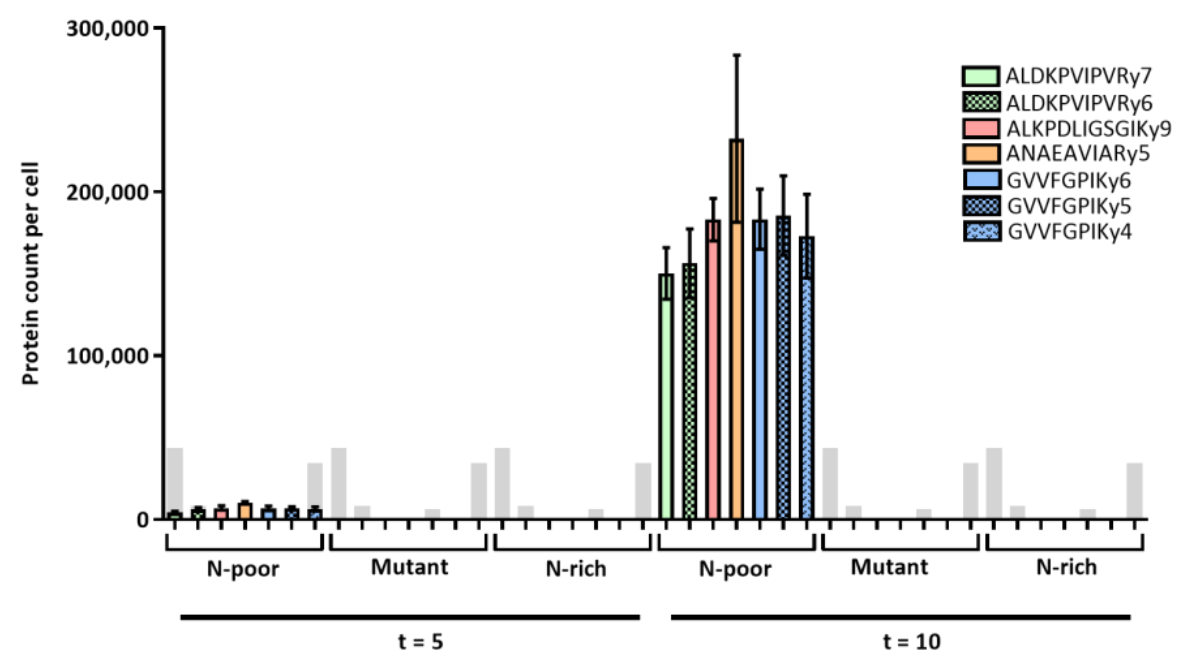

NifH

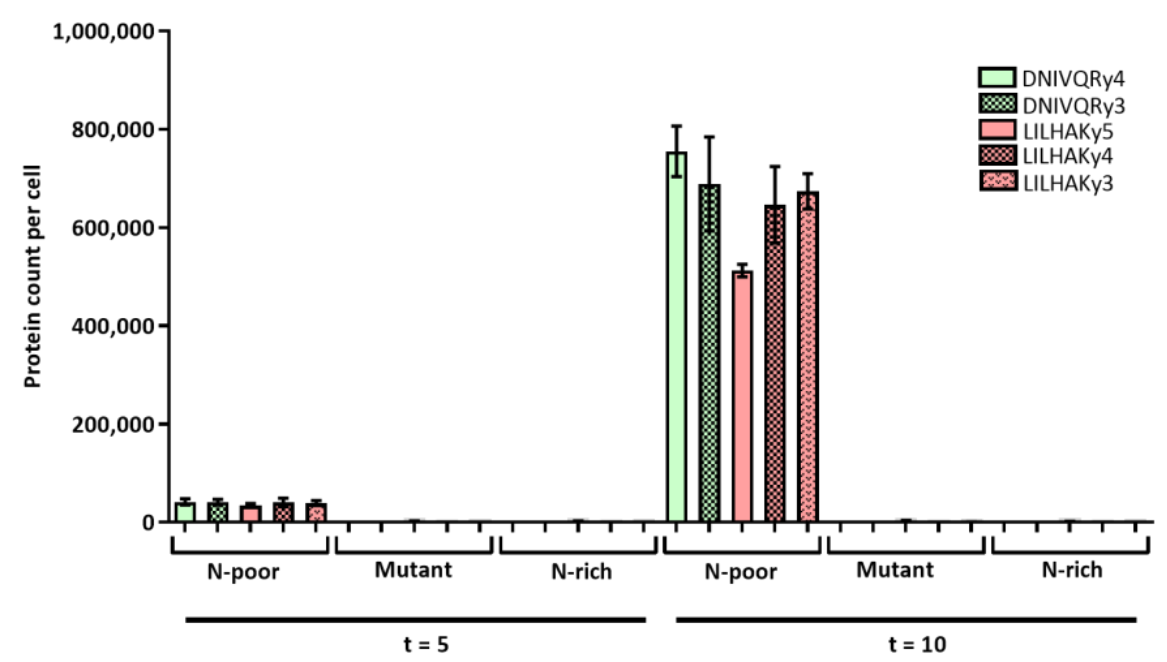




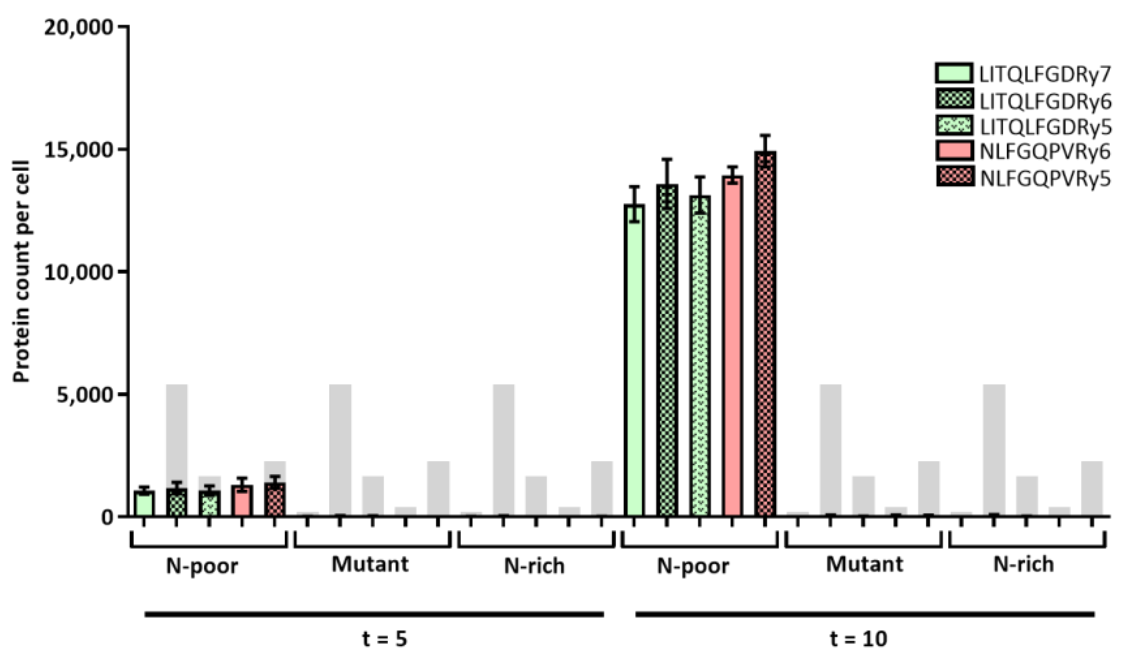

NifF

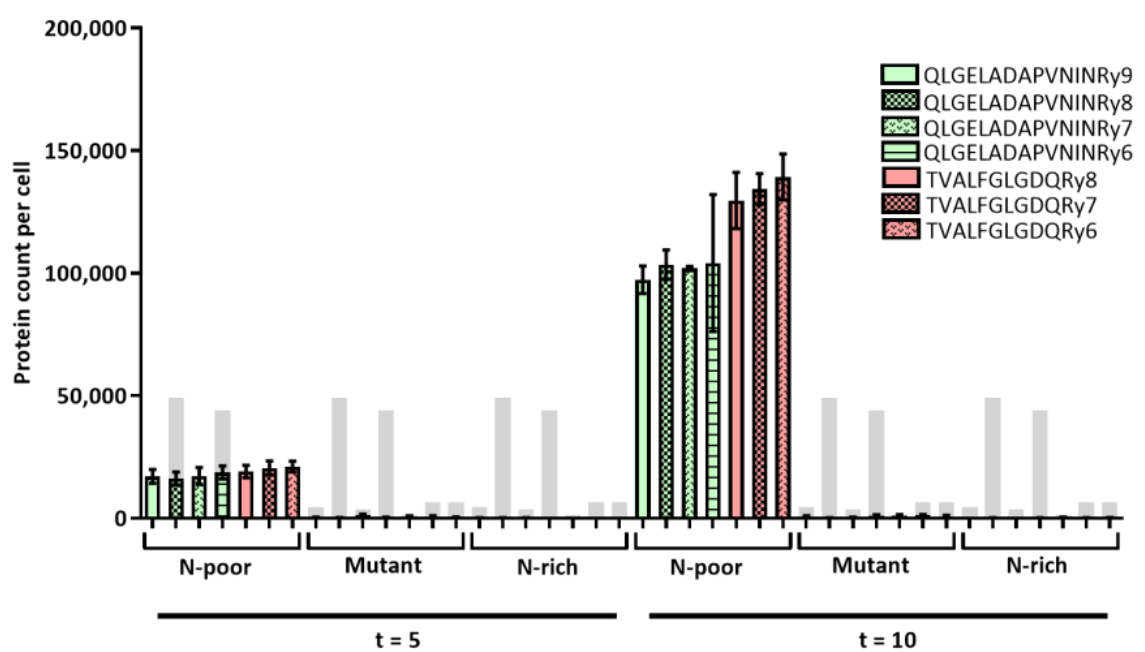

NifA

NifL
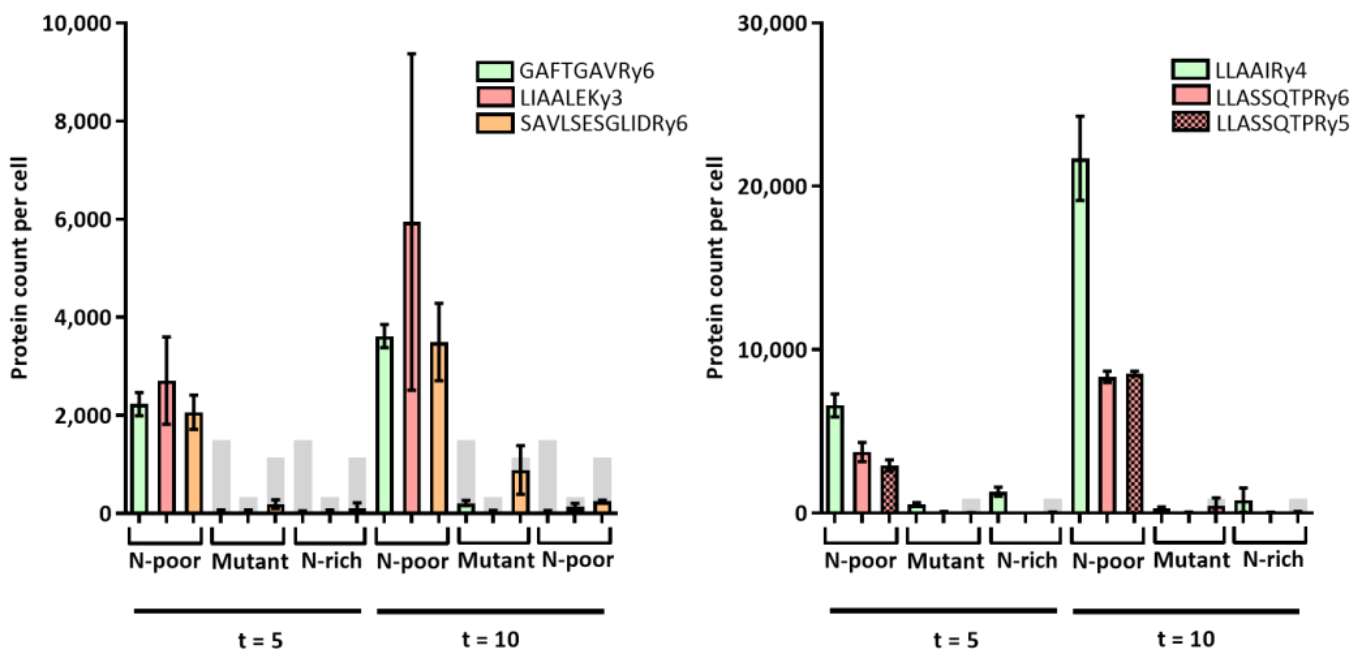
bioRxiv preprint doi: https://doi.org/10.1101/2020.04.27.064014; this version posted April 28, 2020. The copyright holder for this preprint (which was not certified by peer review) is the author/funder. All rights reserved. No reuse allowed without permission.

Figure 3: Protein count per cell for all individual Nif proteins in K. oxytoca M5a1 grown in 0.25 ( $\mathrm{N}$-poor) and 10 (N-rich) $\mathrm{mM} \mathrm{NH}_{4}$, and $K$. oxytoca M5a1 $\Delta$ nifLA (mutant) grown in $0.25 \mathrm{mM} \mathrm{NH}_{4}$, at both 5 and 10 hours after $\mathbf{N}$ sparging. All transitions for each peptide are shown, and limit of quantification illustrated by a filled in light grey bar. Error bars represent SEM over three biological replicates. Protein counts for all other Nif proteins are provided in supplementary file. Note that y-axis scale varies. 
bioRxiv preprint doi: https://doi.org/10.1101/2020.04.27.064014; this version posted April 28, 2020. The copyright holder for this preprint (which was not certified by peer review) is the author/funder. All rights reserved. No reuse allowed without permission.

Nif protein stoichiometries at early $(t=5)$ and late $(t=10)$ transition into $N$ fixation of $K$. oxytoca

To determine the stoichiometries of Nif proteins absolute peptide quantities were averaged between based on counts of individual transitions. Stoichiometries provides information of the biochemical function of the nitrogenase, its assembly and regulation. 


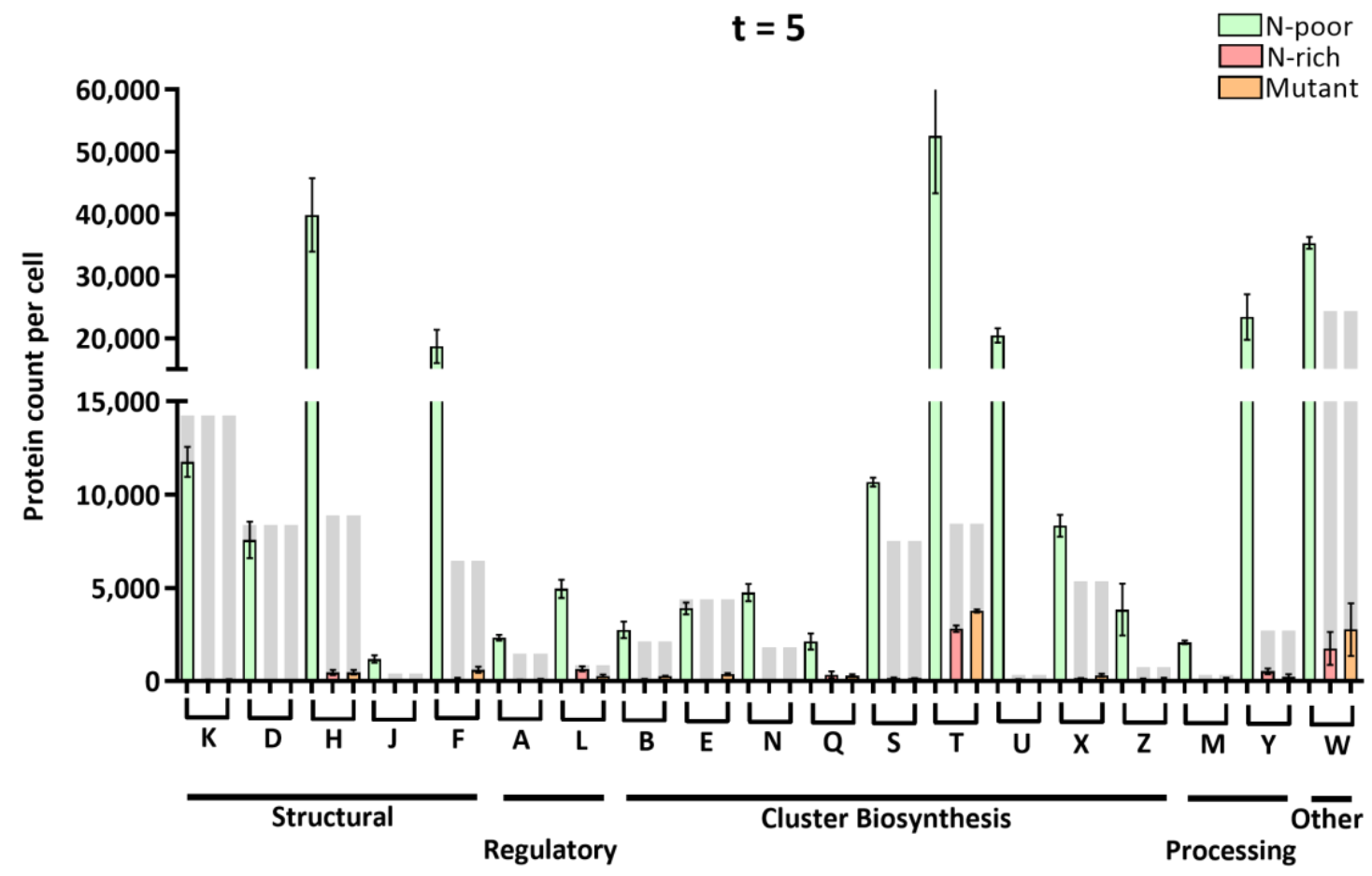

$t=10$

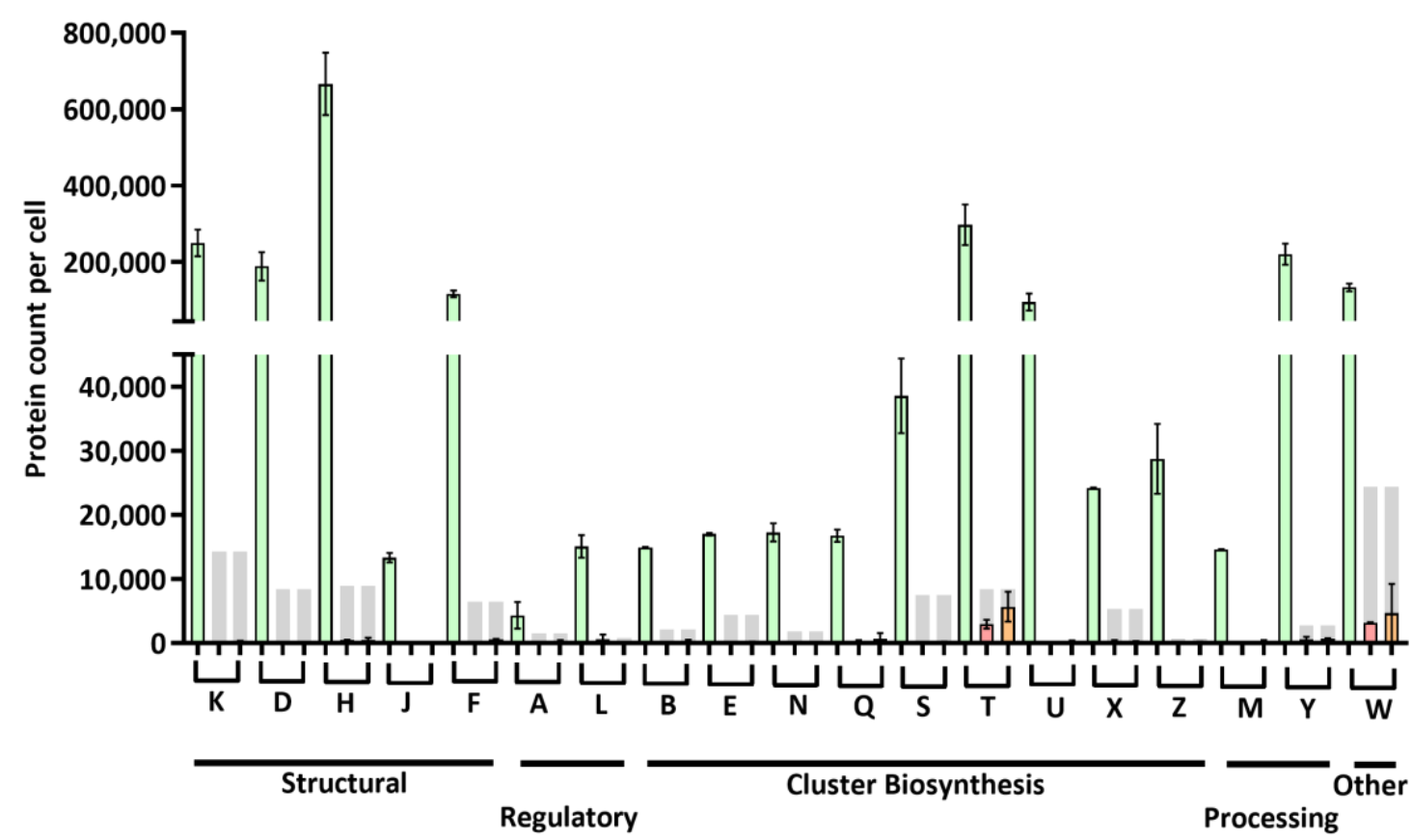

Figure 4: Nif protein stoichiometry at $\mathbf{5}$ and $\mathbf{1 0}$ hours after $\mathbf{N}$ sparging. Values per transition considered to be quantitatively robust were used to give an average per peptide, and these values were averaged in turn to give a value per Nif protein. Proteins are grouped by broad functionality, as indicated along the $x$ axis. $Y$ axes in both cases are split in order to better represent stoichiometry at lower protein counts. Error bars represent SEM over three biological replicates. The highest limit of quantification for each protein, based on figure 8a.II, is illustrated by a filled in light grey bar. 


\section{Discussion}

Since the publication of the QconCAT workflow (24), over 200 QconCATs have been used in a wide range of quantitative proteomic studies and analytical applications. Here we described the design, validation and quality control of a QconCAT approach with MRM-MS to measure 20 Nif proteins of Klebsiella oxytoca. Of the $20 \mathrm{Nif}$ proteins included in the QconCATs, 19 passed the validation process and were quantified. The capability of MRM-MS to produce comprehensive datasets and quantify proteins over a wide dynamic range (32) allowed for quantification of proteins spanning more than 4 orders of magnitude; quantitative measures between 46 and 806630 proteins per cell were recorded.

No transitions corresponding to NifV peptides were visible in both analyte and QconCAT, leading to exclusion for NifV protein analysis. Peptide selection for NifV was problematic due to the very low intensity or non-symmetrical transitions and validation by EPI was not successful for NifV FAENWK and ASGQTLR. In silico digestion parameters had to be significantly broadened to select potential quantotypic peptides. For NifV FAENWK, and NifZ VPVQAIALIEER, peptide signal was observed for the QconCAT but not in bacterial samples. As such, quantification is in theory achievable by enrichment strategies.

\section{Reliability of quantification}

Monitoring several peptides per protein greatly increases reliability of quantification, but can also highlight differences between peptides due to artefactual chemical modifications. These result in a fraction of the target peptide being converted to the modified form in an unpredictable manner (17). An Information Dependent Acquisition (IDA) MS method revealed prevalent modifications on NifD ALDKPVIPVR and NifK AFEVPLIR. Past quantification attempts using QconCATs also revealed discordant quantification data between a significant number of peptides, and suggested that two peptides per protein is inadequate for accurate quantification (15). Nonetheless, peptide modifications through e.g. post-translational modifications can be accurately measured, provided both a non-modified peptide and the modified peptide is included in the labelled standard as has been shown (18). 


\section{Absolute Nif protein abundances and stoichiometries}

The transition of $K$. oxytoca to diazotrophic growth requires a multiplicity of gene products, whose expression is highly coordinated. Steady state abundances of proteins is determined by function, and are based on, for instance, matching stoichiometry between proteins interacting within the same complexes (19). NifE and NifN contribute to FeMo-co biosynthesis by forming an $\alpha 2 \beta 2$ tetramer upon which FeMo-co is built, prior to insertion into the MoFe protein; hence, NifE and NifN are equimolar throughout the time course of this study (supplementary file). In addition, nitrogenase protein structure is such that the ratio expected between NifH, NifD and NifK is 2:1:1 (Figure 3). However, ratios decrease from approximately 5 to $3: 1: 1$ between $t=5$ and $t=10$. As the cell transitions to diazotrophic growth, early NifH abundance is presumably required to also support both P-cluster and FeMo-co synthesis, perhaps explaining why it is present in an apparent excess with respect to known stoichiometry of the nitrogenase complex.

Within functional classes, changes in protein counts and stoichiometry were not always consistent, attesting to complex regulation of $\mathrm{N}$ fixation in $K$. oxytoca. There were, however, a few patterns that emerged. NifA and NifL counts were lower than most other Nif proteins, as is expected from regulatory proteins. NifL protein counts were consistently higher than NifA, perhaps because of the importance, due to high energy costs associated with $\mathrm{N}$ fixation, of a quick and effective sensing of unsuitable $\mathrm{N}$ fixation conditions. As expected, there is a high count of the structural $\mathrm{NifH}, \mathrm{D}$ and $\mathrm{K}$ proteins, and 20 to 30 -fold changes are observed between 5 and 10 hours, such that NifHDK accounts for $33 \%$ of total protein at $\mathrm{t}=10$. As for the Nif proteins involved in cluster biosynthesis and processing, protein count increases from 4 to 10 -fold between 5 and 10 hours, to support the increase in structural protein as $K$. oxytoca transitions into diazotrophic growth. The ratio between cluster biosynthesis/processing and structural Nif protein is higher at $t=5$; early transition into diazotrophy presumably involves accumulation of biosynthetic proteins to a certain level, before upregulation of nitrogenase can be initiated.

Stoichiometry between biosynthetic proteins remained identical between 5 and 10 hours. Fold changes in biosynthetic/processing Nif protein count can be broadly split into a higher (NifQ, Z, B, M, $\mathrm{Y}$ and $\mathrm{T}$ ) and lower (NifE, N, S, U, X) group. Protein counts for the lower group are at least half of their expected value at $\mathrm{t}=10$ if stoichiometry at $\mathrm{t}=5$ was to be preserved. Changes in stoichiometry could suggest that the final biosynthetic system allowing maximal $\mathrm{N}$ fixation has not yet been established. 
Ratios between the nitrogenase components NifDK and Nif proteins involved in cluster biosynthesis and processing give insight into mature nitrogenase assembly mechanics. NifS, $\mathrm{U}, \mathrm{X}$, and $\mathrm{W}$ are all present at excess over the nascent nitrogenase protein at $t=5$, but not at $t=10$. These Nif proteins are presumably important in initial metabolic switching to diazotrophy. Indeed, previous studies have indicated that genes required for early nitrogenase biosynthesis (nifU, nifS) were expressed and turned off earlier than genes required for later stages of the pathway. Once fully functional $\mathrm{N}$ fixation was achieved, demand for biosynthetic components such as NifE, NifN and NifB decreased (8). It is probable that NifB and NifEN can perform multiple enzymatic turnovers in vivo to provide FeMo-co for an excess of NifDK.

Although NifT and NifY to NifDK ratio also decreases between $t=5$ and $t=10$, they are still required at substantial copy number at $t=10$, with more than one NifT and NifY copy per NifDK. Whereas NifY has been characterised as a chaperone for the apo-MoFe protein, the exact role of NifT remains unknown. Given the 1:1:1 molar ratio between NifDK, NifT and NifY, it is possible that NifT also has a chaperone-like role in MoFe protein maturation. A summary scheme of Nif protein stoichiometries and their role in nitrogenase assembly and function is shown in Figure 5. 


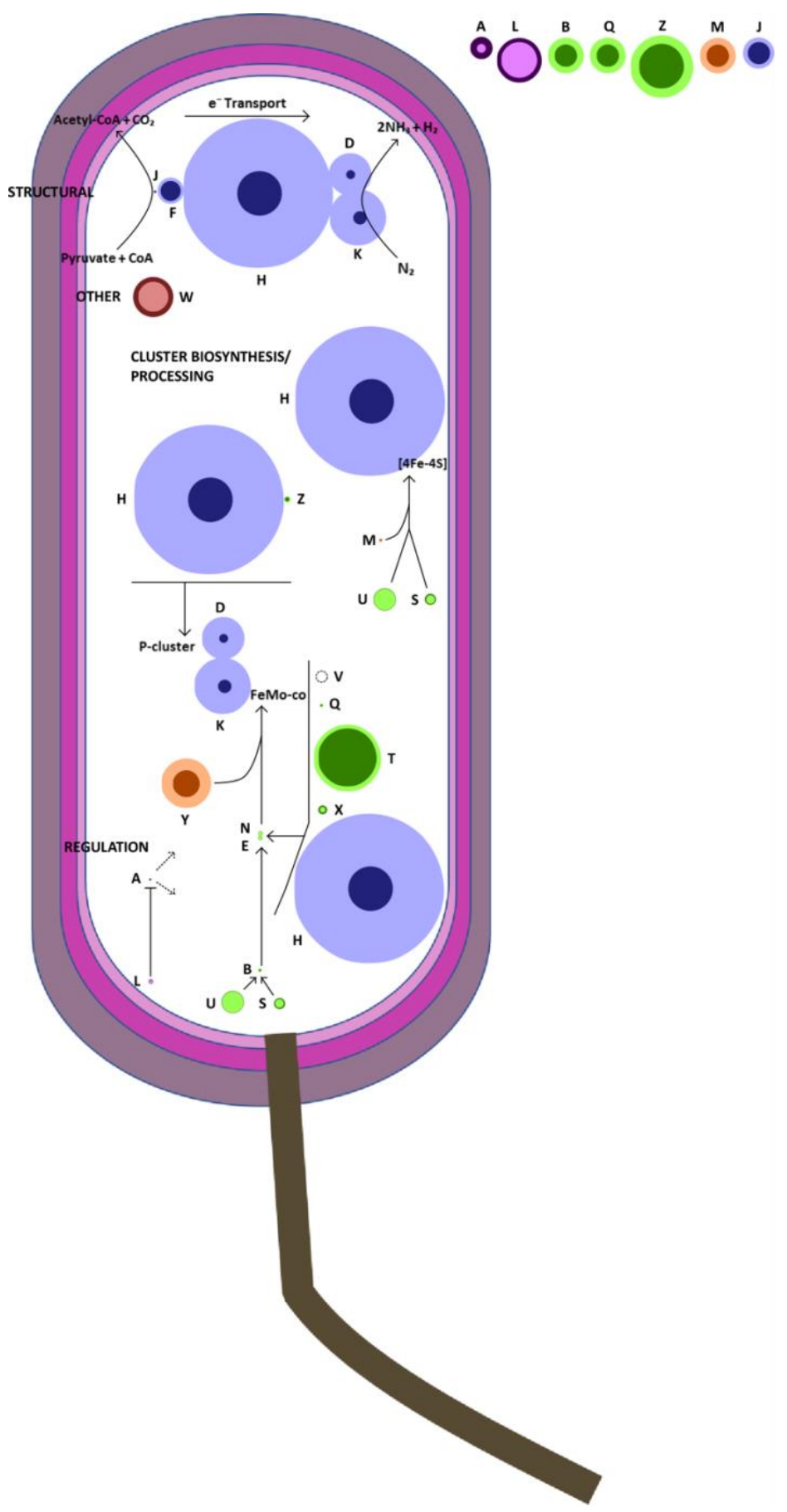

Figure 5: Representation of Nif protein stoichiometry in $\mathrm{N}$-poor samples at $\mathrm{t}=\mathbf{5}$ (dark circle) and $\mathrm{t}=10$ (light circle), with illustration of cluster biosynthesis and nitrogen fixation pathways. Circle diameter is proportional to protein count per cell, with values at $t=10$ halved in order to facilitate presentation. Nif proteins present at low counts are magnified 10-fold and displayed in top right corner of figure. Main classes of Nif proteins are indicated in capitals. Blue tones, structural; green tones, cluster biosynthesis; red tones, other; orange tones, processing; pink tones, regulation. Dotted lines indicate the regulation of nif gene expression by NifLA regulatory system. The role of NifV is indicated by a dotted circle, but no data was obtained for this protein. 
Generally, we found that nif gene expression was very tightly regulated, with most Nif proteins below detection levels under $\mathrm{N}$-rich conditions and up to hundreds of thousands of proteins per cell under diazotrophic growth. This stringent nif regulon control - apparently strictly NifLA dependent - differs from the nitrogen assimilation regulon controlled by $\mathrm{NtrC}$ in $E$. coli, where many genes are expressed despite ammonium starvation, implying complex and $\mathrm{NtrC}$-independent regulatory mechanisms (36). Interestingly, both NifT and NifW are present in the N-rich and $\Delta$ nifLA control samples (Figure 10). It is possible an NifLA-independent regulatory mechanism of these two proteins exists, and their high values explained in part by involvement in other cellular processes. In studying the tolerance of nitrogenase activity to expression levels, NifT has been shown on multiple occasions to not have an effect on nitrogenase activity $(20,21)$, and is often absent from homologous clusters (38).

Previous studies on Azotobacter vinelandii have indicated that each nif operon yields similar mRNA levels for the genes it contains (8). At $\mathrm{t}=10$, a limited amount of agreement with this is observed. In nifHDKTY NifH is higher, in nifENX Nif $\mathrm{X}$ is higher, in nifLA NifL is higher than the remaining gene products of this operon, and in nifUSVWZM NifU and NifW are substantially higher than NifS, NifZ and NifM. However, a substantial number of regulatory processes occur after mRNA synthesis at the posttranscriptional, translational and protein degradation levels, and protein abundance reflects a dynamic balance between these processes. Mass spectrometric analysis, in particular used in conjunction with transcriptomics, can help establish to what extent each of these processes, as well as expression levels, contribute to regulation of cellular protein abundance (19). For instance, in $A$. vinelandii, cellular levels of NifB and NifEN proteins are controlled by the ClpX2 proteins by means of protein degradation, which is induced under diazotrophic conditions (22). Low NifEN and NifB may be the result of this regulatory system. 


\section{Abbreviations}

ATP - Adenosine Triphosphate

UAS - Upstream Activator Sequence

$\sigma^{54}-\sigma^{54}$ RNA polymerase

GS - Glutamine Synthetase

GOGAT - Glutamine Oxoglutarate Aminotransferase

GDH - Glutamate Dehydrogenase

UTase - Uridylyltransferase

UR - Uridylyl Removing

MS - Mass Spectrometry

ORF - Open Reading Frame

QconCAT - Artificial protein encoding a single ORF that is a concatenation of quantotypic tryptic peptides for a group of proteins under study

MRM-MS - Multiple Reaction Monitoring Mass Spectrometry

$m / z$ - Mass/charge ratio

EPI - Enhanced Product lon scan

BSA - Bovine Serum Albumin

LB - Luria-Bertani media

IPTG - Isopropyl $\beta$-D-1-thiogalactopyranoside

SDS-PAGE - Sodium Dodecyl Sulphate Polyacrylamide Gel Electrophoresis

TCEP - Tris(2-chloroethyl) Phosphate

UV - Ultraviolet

DC - Detergent Compatible

LC - Liquid Chromatography

IDA - Information Dependent Acquisition

$\mathrm{N}$-poor - WT K. oxytoca strain M5a1 grown in $0.25 \mathrm{mM} \mathrm{NH}_{4}$

$\mathrm{N}$-rich - WT $K$. oxytoca strain M5a1 grown in $10 \mathrm{mM} \mathrm{NH}_{4}$

Mutant - K. oxytoca M5a1 $\Delta$ nifLA grown in $0.25 \mathrm{mM} \mathrm{NH}_{4}$

GC-MS - Gas Chromatography Mass Spectrometry

SEM - Standard Error of the Mean

WT - Wild-Type 


\section{References}

1. Rockström J, Steffen W, Noone K, Persson Å, Chapin FS, Lambin EF, et al. A safe operating space for humanity. Nature. 2009;461(7263):472-5.

2. Oldroyd GED, Dixon R. Biotechnological solutions to the nitrogen problem. Current Opinion in Biotechnology. 2014;26:19-24.

3. Raymond J, Siefert JL, Staples CR, Blankenship RE. The natural history of nitrogen fixation. Molecular Biology and Evolution. 2004;21(3):541-54.

4. Dixon R, Kahn D. Genetic regulation of biological nitrogen fixation. Nature Reviews Microbiology. 2004;2(8):621-31.

5. Poza-Carrion C, Jimenez-Vicente E, Navarro-Rodriguez M, Echavarri-Erasun C, Rubio LM. Kinetics of nif Gene Expression in a Nitrogen-Fixing Bacterium. Journal of Bacteriology. 2014;196(3):595-603.

6. Hajar Al Feteisi, Brahim Achour, Jill Barber, and Amin Rostami-Hodjegan (2015) Choice of LCMS Methods for the Absolute Quantification of Drug-Metabolizing Enzymes and Transporters in Human Tissue: a Comparative Cost Analysis. AAPS J; 17(2): 438-446.

7. Schumacher J, Behrends V, Pan Z, Brown DR, Heydenreich F, Lewis MR, et al. Nitrogen and carbon status are integrated at the transcriptional level by the nitrogen regulator $\mathrm{NtrC}$ in vivo. Mbio. 2013;4(6):e00881-13.

9. van Heeswijk WC, Westerhoff HV, Boogerd FC. Nitrogen assimilation in Escherichia coli: putting molecular data into a systems perspective. Microbiology and molecular biology reviews : MMBR. 2013;77(4):628-95.

10. MacLean B, Tomazela DM, Shulman N, Chambers M, Finney GL, Frewen B, et al. Skyline: an open source document editor for creating and analyzing targeted proteomics experiments. Bioinformatics. 2010;26(7):966-8.

11. Batth TS, Singh P, Ramakrishnan VR, Sousa MML, Chan LJG, Tran HM, et al. A targeted proteomics toolkit for high-throughput absolute quantification of Escherichia coli proteins. Metabolic Engineering. 2014;26:48-56.

12. Beynon RJ, Doherty MK, Pratt JM, Gaskell SJ. Multiplexed absolute quantification in proteomics using artificial QCAT proteins of concatenated signature peptides. Nature Methods. 2005;2(8):587-9.

13. Pratt JM, Simpson DM, Doherty MK, Rivers J, Gaskell SJ, Beynon RJ. Multiplexed absolute quantification for proteomics using concatenated signature peptides encoded by QconCAT genes. 9Nature Protocols. 2006;1(2):1029-43.

14. Lopez-Cobollo RM, Filippis I, Bennett MH, Turnbull CGN. Comparative proteomics of cucurbit phloem indicates both unique and shared sets of proteins. Plant Journal. 2016;88(4):633-47.

15. Brownridge P, Holman SW, Gaskell SJ, Grant CM, Harman VM, Hubbard SJ, et al. Global absolute quantification of a proteome: Challenges in the deployment of a QconCAT strategy. Proteomics. 2011;11(15):2957-70. 
16. Gasteiger E, Gattiker A, Hoogland C, Ivanyi I, Appel RD, Bairoch A. ExPASy: the proteomics server for in-depth protein knowledge and analysis. Nucleic Acids Research. 2003;31(13):3784-8.

17. Lange V, Picotti P, Domon B, Aebersold R. Selected reaction monitoring for quantitative proteomics: a tutorial. Molecular Systems Biology. 2008;4.

18. Gosztolai A, Schumacher J, Behrends V, Bundy JG, Heydenreich F, Bennett MH, et al. GlnK Facilitates the Dynamic Regulation of Bacterial Nitrogen Assimilation. Biophysical journal.

2017;112(10):2219-30.

19. Vogel C, Marcotte EM. Insights into the regulation of protein abundance from proteomic and transcriptomic analyses. Nature Reviews Genetics. 2012;13(4):227-32.

20. Temme $K$, Zhao D, Voigt CA. Refactoring the nitrogen fixation gene cluster from Klebsiella oxytoca. Proceedings of the National Academy of Sciences. 2012;109(18):7085-90.

21. Simon HM, Homer MJ, Roberts GP. Perturbation of nifT expression in Klebsiella pneumoniae has limited effect on nitrogen fixation. Journal of Bacteriology. 1996;178(10):2975-7.

22. Martinez-Noel G, Curatti L, Hernandez JA, Rubio LM. NifB and NifEN protein levels are regulated by $\mathrm{ClpX} 2$ under nitrogen fixation conditions in Azotobacter vinelandii. Molecular Microbiology. 2011;79(5):1182-93. 